\title{
ETHICS IN DISSECTION OF CADAVER IN TEACHING AND LEARNING OF ANATOMY
}

\author{
Abu Sadat Mohammad Nurunnabi ${ }^{1}$, Shamim Ara $^{2}$, Mohsin Khalii ${ }^{3}$, Mansur Khalii ${ }^{4}$ \\ 1. Dr. Abu Sadat Mohammad Nurunnabi, Lecturer, Department of Anatomy, Dhaka Medical College, Dhaka. Cell \\ Phone: +8801712290608, Email: shekhor19@yahoo.com (corresponding Author). \\ 2. Dr. Shamim Ara, Professor and Head, Department of Anatomy, Dhaka Medical College, Dhaka. \\ 3. Dr. Mohsin Khalil, Professor and Head, Department of Anatomy, Mymensingh Medical College, Mymensingh. \\ 4. Dr. Mansur Khalil, Professor and Head, Department of Anatomy, Chittagong Medical College, Chittagong.
}

\begin{abstract}
Dissection of dead body is a time honoured part of medical education. Undergraduate and postgraduate students do dissection as a part of the learning human anatomy. According to the state regulations, most of the cadavers are obtained from the forensic mortuary declared as 'unclaimed body'. Some are collected through 'body donation' as well. However, use of human tissue for research and the use of human cadavers for teaching and training purposes are surrounded by ethical uncertainties. Moreover, the main ethical concern of cadaver dissection lies in respect to human life. This writing has been aimed to put a nominal guideline how to act in an ethical way in cadaver dissection by the medical students in medical colleges and pave the way for better understanding how to respond in an ethical manner in medical professional life. Some rules and regulations have been recommended for maintaining the highest standard of a dissection hall as well as the dignity of the cadavers.
\end{abstract}

Key words: Ethics, Dissection, Cadaver, Teaching and learning anatomy.

Introduction: The most important book in the history of medicine is an anatomical treatise published in 1543, 'De humani corporis fabrica', based on dissections of the human body. The illustrations in the seven volumes of this work by Andreas Vesalius are exquisite for their beauty, complexity and humanity ${ }^{1}$. Prior to Vesalius anatomical texts were based largely on dissections of nonhuman animals. However, cadaver dissection was not new in the time of Vesalius, where there was a physician-teacher performed dissection in the theatre surrounded by the students ${ }^{1,2}$. 
Cadaveric dissection has been the paradigm of anatomy teaching since the Renaissance, and the defining experience of medical teaching since the $16^{\text {th }}$ and $17^{\text {th }}$ centuries ${ }^{3,4}$. Subsequently, cadaveric dissection featured regularly in medical training, although often in an informal, semi-official manner ${ }^{5}$. Even with the current tools available to the western countries such as the Visible Human Project, students still begin the study of human anatomy at the dissecting table both in eastern and western world.

Dissection of cadaver - essential part of teaching and learning anatomy: Cadavers are required for studying the human anatomy in all disciplines of medical science. As medical institutions of various specialized disciplines have overgrown, the need for cadavers has also increased proportionately ${ }^{6}$. Cadavers used by these institutions are usually unclaimed bodies obtained by the police in our country. Occasionally they are donated by relatives of the deceased, to teaching institutions, according to the dead person's wishes ${ }^{7,8}$. Donating one's body for dissection meets the criteria for the highest levels of charity as set forth by the $12^{\text {th }}$ century philosopher, physician, and rabbinic scholar Moses Maimonides ${ }^{9}$.

Ethical concerns in dissection of cadavers: Anatomical dissection is a time honoured part of medical education ${ }^{5}$. However, like the use of human tissue for research purposes, the use of human cadavers for teaching and training purposes is surrounded by ethical uncertainties ${ }^{9-12}$. Ethical problems are recognized as one of the reasons for thinking to take decision to abandon anatomical dissection altogether in the U.K. (e.g. newly founded Peninsula Medical School in Plymouth) as stated by McLachlan et al. ${ }^{13}$. At the heart of such uncertainties lies the ambiguous status of the cadaver, which carries at the same time personal and material qualities ${ }^{10}$. This ambiguity is not easily resolved, which explains why the dissecting room experience can be frightening and fascinating ${ }^{14}$. The main ethical concern of cadaver dissection lies in respect to human life.

Rules and regulations for working in the dissection hall: The students in our country have got enormous opportunity of dissecting cadavers and learning themselves, especially in government medical colleges, where there are morgues for medicolegal autopsy purposes. Therefore, it is a great opportunity to participate in a rich tradition and experience a privilege shared by only few. Cadavers are referred to as 'human anatomical specimens ${ }^{, 15}$, a description that seems inadequate for such a valuable gift to medical 
education. Working with human material requires respect and sensitivity ${ }^{16}$. The following information and rules will help the students and the teachers understand their responsibilities regarding the use of human material.

Here are some rules and regulations for maintaining the highest standard of a dissection hall as well as the dignity of the cadavers:

1. Human Anatomical Gifts: We stated earlier that the most of our cadavers were obtained from the college mortuary declared as 'unclaimed body', according to the state regulations. Some are collected through 'body donation'. Persons donating their body receive no financial compensation; this is truly their ultimate gift $^{17}$. Hence, it is imperative that proper respect be paid to the cadaver at all times. Any disrespect for the cadaver will be shameful as a human being ${ }^{18}$. The teachers and the students should observe professional conduct while in the dissection hall and outside of the hall, particularly if anyone wants to discuss anything related to the cadaver in a public place. Photographs of the cadaver or any parts should not be taken inside the dissection hall without prior permission.

2. Care of Cadavers: The cadaver has to be kept moist at all times. The cadaver is covered with towels moistened with embalming fluid. The students should only uncover the area they are studying.

3. Laboratory Access: The dissection hall should have got a limited access and needs to be locked when not in use. Only students enrolled in the course are allowed in the dissection hall. The students should not bring in friends or visitors! Of course, this may differ in accordance with different institutional rules.

4. Laboratory Safety: Cadavers are embalmed with a fluid containing glycerin, ethyl alcohol and phenol. Physical contact of one's skin and clothing with the cadaver should be avoided. The students are required to wear disposable gloves at all times while working in the dissection hall. Non-latex/powderless gloves should be available for dissection. However, in our country, dissection is done without wearing hand gloves in many medical institutions. A long-sleeved white coat/apron should be worn while working with the cadaver. Lab coats may not be worn outside of the lab. Dirty coats are a health hazard and are offensive. No open-toed shoes or sandals are allowed. The students should wear shoes that cover their entire foot. Contact lenses should not be worn in the dissection hall, because the lenses can absorb 
chemical vapours. If anyone must need to wear contact lenses, he/she is required to purchase and wear vapour proof goggles. Only textbook and dissection manual are allowed in the dissection hall. All backpacks or other personal items should be left at a corner. Food and drinks are not allowed in the dissection hall. Proper use and handling of the dissection instruments should be carefully maintained. The ventilation system in the hall is designed to remove air at the level of the cadaver and to reduce exposure to the embalming chemicals and odours. The ventilation system should remain on at all times. There is a negative air flow to keep odours from leaving the hall. The door to the hall should be closed at all times.

5. Preservation of the tissues and organs: All tissues removed from the cadaver must be collected and placed in the designated containers or tray. No body parts, tissue, etc. should be removed from the dissection hall. The excess liquid that has accumulated on the dissection table should be drained into the bucket located under the table.

The last word - lost in translation: Anatomy is a rigorous course requiring great dedication and devotion. Just as dissection remains an essential technique to teach three-dimensional concepts, the cadaver dissection hall is an ideal place to introduce concepts of humanistic care ${ }^{14}$. The dissection hall evokes the students' memories, speculations, and fears about serious illness in themselves, their families, and loved ones ${ }^{19}$. The attitude of the lecturers/curator (as they are engaged in dissection classes for the students in our country) in ministering to the students' needs as they undertake the emotionally charged task of dissection can provide a model for how the students will respond, in turn, to the hopes and fears of their patients and to their own reactions to dying. This approach will allow students to implement and practice humanistic values immediately, laying a foundation for their clinical training ${ }^{20}$.

We are actually not in a position to judge whether the ethical approach will produce better doctors in the end. However, we like to think that it allays some of the ethical difficulties in dealing with human cadavers. Of course, medical practitioners face many ambiguities, including the need to show both detachment and empathetic care in the treatment of patients ${ }^{21}$. Therefore, learning how to deal with such ambiguities is in itself an important aspect of medical education and training ${ }^{13}$. In this respect, everyone engaged in teaching and learning should follow the ethical ways. This writing was aimed to put a nominal guideline 
for ethical way of act in cadaver dissection and pave a way for better understanding how to respond in ethical manner in medical professional life.

Last but not the least, we want to share a quote from the students' words of condolence for their body donor, experienced in Thailand, where the cadavers are always referred to as 'ajarn yai' (great teacher), never as 'sop' (cadaver).

"I would like you to know that to me and many others you are a hero.

Your sacrifice is silent, most people don't know about it. But I promise,

I will never forget you. You have taught me everything there is to be learnt both

In the book and in the facts of life. I will remember you as my great teacher forever."

[From a booklet for a cremation ceremony at Mahidol University, Bangkok, Thailand - the original text in English $]^{14}$.

\section{References:}

1. Rath G, Garg K. Inception of cadaver dissection and its relevance in present day scenario of medical education. J Indian Med Assoc 2006; 104(6): 331-3.

2. Hildebrandt S. Capital punishment and anatomy: history and ethics of an ongoing association. Clin Anat 2008; 21: 5-14.

3. Richardson R. Death, dissection and the destitute. London: Penguin; 1988.

4. Persaud TVN. The early history of human anatomy: from antiquity to the beginning of the modern area. Illinois: Thomas Books; 1984.

5. McLachlan JC, Patten D. Anatomy teaching: ghosts of the past, present and future. Med Educ 2006; 40(3): 243-53.

6. Pampilly VS. Cadavers for anatomical dissection. Indian J Med Ethics 2005; 2(1): 16-7.

7. Dyer GS, Thorndike ME. Quidne mortui vivos docent? The evolving purpose of human dissection in medical education. Acad Med 2000; 75(10): 969-79.

8. Furness P. Consent to using human tissue. BMJ 2003; 327: 759-60. 
9. Sukol RB. Building on a tradition of ethical consideration of the dead. Hum Pathol 1995; 26(7): 700-5.

10. Hafferty FW. Cadaver stories and the emotional socialization of medical students. J Health Soc Behav 1988; 29: 344-56.

11. Tuffs A. Von Hagens faces investigation over use of bodies without consent. BMJ 2003; 327(7423): 1068.

12. Shaffer K. Becoming a physician: teaching anatomy in the digital world. N Engl J Med 2004; 351: 1279-81.

13. McLachlan JC, Bligh J, Bradley P, Searle J. Teaching anatomy without cadavers. Med Educ 2004; 38(4): 418-24.

14. Winkelmann A, Güldner FH. Cadavers as teachers: the dissecting room experience in Thailand. BMJ 2004; 329(7480): 1455-7.

15. Baumel JJ. Donation of bodies for medical education. Nebr State Med J 1968; 53(3): 90-2.

16. Pawlina W, Hammer RR, Strauss JD, Heath SG, Zhao KD, Sahota S, et al. The hand that gives the rose. Mayo Clin Proc 2011; 86(2): 139-44.

17. Yeager VL. Learning gross anatomy: dissection and prosection. Clin Anat 1996; 9(1): 57-9.

18. Pawlina W, Lachman N. Dissection in learning and teaching gross anatomy: rebuttal to McLachlan. Anat Rec B New Anat 2004; 281(1): 9-11.

19. Rizzolo LJ. Human dissection: an approach to interweaving the traditional and humanistic goals of medical education. Anat Rec 2002; 269(6): 242-8.

20. Bertman SL, Marks SC, Jr. The dissection experience as a laboratory for self-discovery about death and dying: another side of clinical anatomy. Clin Anat 1989; 2(2): 103-13.

21. Rosenfield PJ, Jones L. Striking a balance: training medical students to provide empathetic care. Med Educ 2004; 38: 927-33. 